\title{
Siyasal İletişimde Bilişimsel Propaganda: Türkiye'de 23 Haziran 2019 İstanbul Yerel Seçimleri ve Botlar, Cyborglar, Troller*
}

\author{
Political Communication in Computational Propaganda: 23 June 2019 Istanbul Local Elections and \\ Bots, Cyborgs, Trolls in Turkey**
}

Barış Yetkin, Dr. Öğr. Üyesi, Giresun Üniversitesi Tirebolu İletişim Fakültesi, E-posta: baris.yetkin@giresun.edu.tr

https://doi.org/10.47998/ikad .785151

Anahtar Kelimeler:
Siyasal İletişim,
Bilişimsel Propaganda,
Sosyal Medya,
Twitter,
Botlar,
Cyborglar,
Troller.

Öz

Sosyal medya kullanımının ayrılmaz parçaları olan trol, bot ve cyborg gibi araçlar, bilişimsel propaganda etkileriyle demokrasiyi tehdit etmeye başlamışlardır. Bu nedenle,

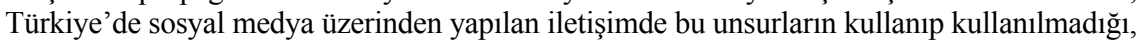
kullanıldıysa hangi oranda kullanıldığının bulunması önemli bir meseledir ve araştırmaya değerdir. 23 Haziran 2019 Seçimleri, böylesi bir araştırma için iyi bir ortam sunmaktadır.

Bu araştırmada Türkiye'de Twitter trafiği içerisinde trol, bot ve cyborg hesapları konu edinilmiştir. 2019 Haziran İstanbul Büyükşehir Belediye Başkanlığı seçimlerinde aday olan Binali Yıldırım ve Ekrem İmamoğlu'nun Twitter seçim kampanyalarını yürüttükleri hesapların takipçilerine, iletilerine etkileşimli olarak katılan ve katkı sağlayan hesaplara odaklanılmıştır.

Araştırmanın amacı, Türkiye'de Twitter trafiği içerisinde trol hesaplarının yanı sıra bot ve cyborg hesaplarının yaygın olup olmadığını belirlemesidir. Adayların hashtagler'inin diğer kullanıcılarca hangi kaynaklardan dolaşıma sokulduğu GitHub TCAT açık kaynak yazılımıyla gerçekleşmiştir. Bot ya da cyborg şüphelisi hesaplara rastlanmış; en aktif ikişer tanesi a ğ analizi ve görselleştirme yazılımı olan Gephi ile takibe alınmıştır. Araştırma sonucunda cyborg ve bot gibi otomatikleşmiş hesaplara rastlanmış; bu türden hesapların yalnızca siyasetçilerin takipçi kullanıcıları tarafından değil, kamu gündemi yaratmaya çalışan çıkar grupları tarafından da kullanılmaya başlandığı sonucuna ulaşılmıştır.

\section{Keywords:}

Political Communication, Computational Propaganda, Social Media, Twitter, Bots, Cyborgs, Trolls.

\section{Abstract}

Tools such as trolls, bots and cyborgs, which are an integral part of the use of social media, began to threaten democracy with the effects of computer propaganda. For this reason, it is an important question and worth investigating whether these elements are used in communication via social media in Turkey, and to what extent they are used if they are used. The June 23, 2019 elections provide a good setting for such research. The elections of 23 June 2019 provide a good environment for such research.

In this study, troll, bot and cyborg accounts were acquired in Twitter traffic in Turkey. Binali Yildirim and Ekrem Imamoglu, candidates for the 2019 June Istanbul metropolitan mayoral elections, focused on the accounts that interact with and contribute to their followers, messages, and Twitter election campaigns.

The purpose of the study is to determine whether troll accounts, as well as bot and cyborg accounts, are common in Twitter traffic in Turkey. The sources from which the candidates ' hashtags were circulated by other users were realized through the GitHub TCAT open-source software. Bot or cyborg suspect accounts were encountered; The most active two of them were followed up with Gephi, the network analysis and visualization software. As a result of the research, automated accounts such as cyborg and bot were found; it was concluded that such accounts were being used not only by the followers of politicians, but also by interest groups trying to create a public agenda.

\footnotetext{
*Bu makale 24-25 Temmuz 2020 tarihleri arasında Van Türkiye'de düzenlenen Van Uluslararası Sosyal Bilimler Kongresi adlı etkinlikte sözlü bildiri olarak sunulmuş ve özeti kongre bildiri özet kitabında basılmış Siyasal İletişimde Bilişimsel Propaganda: Türkiye'de 23 Haziran 2019 İstanbul Yerel Seçimleri ve Botlar, Cyborglar, Troller” başlıklı bildirinin tamamlanmış halidir. ** This article is the final version of the paper titled "Political Communication in Computational Propaganda: 23 June 2019 Istanbul Local Elections and Bots, Cyborgs, Trolls in Turkey", which was presented as a verbal paper at the event Van International Social Sciences Congress held in Van Turkey between 24-25 July 2020 and the abstract was published in the congress abstract book.
}

Araştırmacı Orcid ID : : https://orcid.org/0000-0003-0577-3363

Geliş Tarihi 


\section{Giriş}

Günümüzde yaşamın her alanında olduğu gibi siyasetin niteliğinde de birtakım dönüşümlerden söz edilebilir. Sosyal medya platformlarının kullanıcı sayılarında sürekli artış gözlemlenmektedir. Kamunun dijital ortama yansıması biçiminde tezahür eden bu durum, sosyal medyayı kamuoyu oluşturmada önemli bir araç haline getirmektedir. Sosyal medyanın böylesine yaygınlaşması, kitlelerle sürekli iletişim içinde olma çabasındaki şirketlerin, kamu kuruluşlarının, siyasal aktörlerin, popüler olmak isteyenler gibi söyleyecek bir şeyleri olan tüm kişilerin dikkatini her zamankinden daha çok çekmektedir. Bu durum, sosyal medya kullanıcı sayılarının artması anlamına gelmektedir. Ancak, sosyal medya yalnızca insan kullanıcı hesaplarından oluşmamaktadır.

İnternet kullanıcılarının ortaklaşa içerik üretmeleri anlamını taşıyan 'Web 2.0' ile birlikte eş zamanlı olarak yapay zekaların, diğer bir deyişle algoritmik bilinçlerin yaygınlaşmasını çağrıştıran 'Siyaset 2.0' devreye girmiştir.' Öyle ki, 'bot' olarak adlandırılan sosyal medya robotlarının hem üretim hem de kiralanma maliyetinin ucuz olması, kullanım yaygınlığını beraberinde getirmektedir. Bot üretimi için gerekli yazılımların satın alınması ve az sayıda operatör ile yüzlerce hatta binlerce insan taklitli bot hesabın üretilmesi ve yönetilmesi siyasal aktörlerin seçim kampanyalarında önemli unsur haline gelebilmektedir. TweetDeck ve Twitter Web gibi internet arayüzleri bir kullanıcının birden çok hesabın kontrol etmesine izin verirlerken, Botize, MasterFollow, UberSocial gibi servisler -içeriği dağıtacak bot hesapların doğrudan kontrol etmelerini sağlamasa da- içerik yüklemelerine ve ileti programını yönetmelerine izin vermektedirler (Howard vd., 2018: 85). Bunların dışında, doğrudan bot hesap yönetim programı olan Zeus'un satış fiyatı 700 USD civarındadır. Sahte takipçi hesaplar, fiverr.com gibi internet sitelerinde 5 ile 10 USD bir maliyetle kolayca bulunabilmektedir. Aynı şekilde, kiralama yöntemiyle istenilen türden (Türk/yabancı, kadın/erkek) kimliğe sahip hesaplara çeşitli hizmet (tweet, retweet, beğeni vb.) bedelleri karşılığında ödenen kiralamalar da düşük maliyetli olabilmektedir. ${ }^{2}$

Siyasal partiler gibi örgütlenmelerin sosyal medya üzerinden bireylere ulaşmasının bir diğer yolu ise, daha geleneksel biçimde, kendi yapısı içinden olabilmektedir. Türkiye'de çeşitli partilerin sosyal medya iletişim merkezleri bulunmakta; hedef kitlelerine uygun olarak gençlik kolları aktif olarak eylemlerde bulunurlarken, "Genç Siviller", "Milli Görüş Erleri”, “AkTroller” gibi benzer adlarla anılabilmektedirler.

Dünya genelinde olduğu gibi Türkiye'de de internet, sosyal medya, mobil araçların kullanım sayılarında hızlı bir artış dikkat çekmektedir. 2018 yılı itibariyle Türkiye'de internet ve sosyal medya kullanıcı sayıları üçer milyon kişi ile ortalama yüzde beş oranında artmaktadır. En etkin sosyal platformları, görsel ağırlıklı olanların ardından

1 Dünyanın çeşitli yerlerinde; endüstride üretim robotlarının yanı sıra, örneğin Japonya'da bir robotun belediye başkanı adayı olması (Milliyet, 16 Nisan 2018; Posta, 17 Nisan 2018), robot gazetecilerin daha etkin görev almaları (Habertürk, 12 Mart 2010; BBC, 18 Mart 2014; Sözcü, 31 Temmuz 2017) ya da bu araştırmada ele alınan sosyal medya robotlarının ticari ve siyasi amaçlarla kullanılmaları gibi örneklere rastlanabilmektedir. Elbette, tüm bunlar, Web 3.0 ile birlikte siyaset 3.0'ın çok yakında devreye gireceğinin habercileridirler.

2 Daha ayrıntılı bilgi için bkz. Ek-1. 
düşünce paylaşımının daha etkin yapılabildiği Twitter gelmektedir. ${ }^{3} \mathrm{Bu}$ durum, Twitter' 1 kitlelerle etkin iletişim içine girilebilecek platformlardan biri haline getirmektedir.

Türkiye'de özellikle 30 Mart 2014 Yerel Seçimleri ile birlikte geçmişe oranla daha yoğun ve etkin sosyal medyanın yanı sıra hem otomatikleşmiş hem de trol hesapların kullanımı kamuoyu gündemine taşınmıştır. ${ }^{4}$ Sosyal medya kullanımının ayrılmaz parçaları olan trol, bot ve cyborg gibi araçlar, bilişimsel propaganda etkileriyle kamuoyu oluşturmaktadır. Bu nedenle, Türkiye'de sosyal medya üzerinden yapılan iletişimde bu unsurların kullanıp kullanılmadığı, kullanıldıysa hangi oranda kullanıldığının bulunması önemli bir meseledir ve araştırmaya değerdir. 23 Haziran 2019 Seçimleri, böylesi bir araştırma için iyi bir ortam sunmaktadır.

\section{Dijital Etki Çarpanları}

Botların ve diğer etkenlerin anlaşılması için öncelikle sosyal medya tanımlanmalıdır. Farklı boyutlarda sosyal medya; (a) bireysel değeri olan ancak paylaşılan değerleri yansıtan içerik üretmek ve dağıtmak için kullanılan bilgi altyapısı ve araçlarından oluşur; (b) kültürel mesajlar haline gelen kişisel mesajların, haberlerin ve fikirlerin dijital biçimini alan içerik ve (c) hem araçları hem de içeriği üreten ve tüketen insanlar, kuruluşlar ve endüstriler biçiminde tanımlanabilir (Wooley ve Howard, 2016: 4885). Diğer sosyal medya platformlarında olduğu gibi Twitter organik, melez ya da algoritmik hesaplar üzerinden çalışır. İnsan hesapların yanı sıra, resmi olarak varlıkları inkâr edilmeyen cyborglar, botlar gibi alt kategoriler olarak sosyal medyanın tüm boyutları boyunca hareket edebilmektedirler.

\section{Botlar}

Bot kavramı, çevrimiçi olarak belirli görevleri yapmak için tasarlanmış, algoritmik olarak çalışan, insanları taklit eden ve çok büyük miktarda bilgi üreten bilgisayar programları (Wooley ve Howard, 2016: 4885) olarak tanımlanabilir. En basit anlatımla, tamamen ya da kısmen yazılım araçları tarafından denetlenen sosyal medya hesaplarıdır. Botlar, bilgi ve bilginin iletilme biçimine müdahale etmek üzere programlanmış algoritmik medya öğelerinin bir alt kategorisi olarak düşünülebilir (Murthy vd., 2016: 4955).

Siyasal botlar ise, çeşitli sosyal medya ve aygıt ağları yelpazesinde kamuoyu oluşturmak üzere gerçek insanlardan öğrenmek ve taklit etmek için yazılmışlardır. Bu tür botlar, Twitter gibi sosyal medya platformlarında ve Wikipedia gibi toplum tarafından korunan sitelerde diğer kullanıcılarla etkileşime giren çeşitli otomatik bilgisayar komut dosyalarıdırlar (Wooley ve Howard, 2016: 4885) ve (1) etkinlik, (2) güçlendirme ve (3) anonimlik gibi üç temel farklı amaçtan biri ile görevlendirilirler (Nimmo, 2016).

3 Örneğin, facebook.com'da aylık 785 bin 500 trafik ile 11 dakika 28 saniye zaman geçiriliyorken her ziyarette 11,6 sayfa açılmakta; twitter.com'da ise, trafik sayısının aylık 188 bine düşmesine karşın, 10 dakika 37 saniye zaman geçiriliyorken her ziyarette 9,5 sayfa açılmaktadır (Kemp, 2018).

4 Seçime katılan siyasal aktörler kamuoyu oluşturan kesimlerle iletişimlerinde sosyal medyayı daha etkin olarak kullanacaklarını çeşitli firsatlarda açıkça beyan etmişler; kampanya süreçlerinde bu etkinlikleri açıkça dikkat çekmektedir. 
Bir ağ (botnet) içinde düşünüldüğünde botlar işlevlerine göre çeşitlenmektedir. ${ }^{5}$ İyi ve kötü karakterli olabilen botların ticari ve siyasal amaçlı kullanımları söz konusudur. Siyasal botlar, örneğin, takipçi sayısının artırılması ve Twitter'daki siyasi adayların içeriğinin yeniden gözden geçirilmesi, Facebook'taki siyasi rakiplere saldırılması ya da Reddit $^{6}$ gibi platformlarda aktivistlerin konuşmalarla oyalanması (Wooley ve Howard, 2016: 4885), kamuoyunun manipüle edilmesi, tartışmaların aksaklığa uğratılması, bulanık siyasal sorunların çözülmesi (Howard vd., 2018: 83) gibi görevleri yerine getirmektedirler. Örneğin, ABD'de seçim kampanyalarında, (1) zombi seçim kampanyası (propagandası) ve AstroTurf' yasama kampanyaları, (2) kampanya stratejisini ve mesajlaşmayı karmaşık yollarla koordine etmek, (3) seçmenlerin para ve zamanlarını kampanya yararına ayırmalarını istemek amaciyla kullanılabilmektedirler (Howard vd., 2018: 88). Elbette, klasik kapmayalar gibi siyasal bot kampanyaları da fikirleri manipüle edebilmek için önemli miktarda sosyal, zamansal ve parasal sermaye gereksinim duyarlar (Murthy vd., 2016: 4954).

\section{Cyborglar}

Bir diğer alt kategori olan cyborglar ise, bir hesabın içerik üretiminde, yardımcı komut dosyaları kullanılarak bir insan tarafindan işletilmesi ile oluşan bot ve insan arasında yer alan ara (melez) yapılardır (Sanovich vd., 2018). Amaca yönelik olarak, böylesi insan-yazılım melezlerin yaygın kullanımı ve ardındaki algoritmalar sosyal medya sistemlerinin siyasal doğasını tehdit eder durumdadırlar (Wooley ve Howard, 2016: 4885). Çünkü bot-destekli insanlar ve insan-destekli botlar olarak alt sınıflandırılması yapılan bu kategoride (Chu vd., 2012), siyasal troller manipülasyonda olduklarından daha yetenekli hale gelmektedirler.

\section{Troller}

Bilişimsel propagandanın diğer ajanlarından olan troller kimi yönlerden benzer özellik taşıyabilmektedirler. Çevrimiçi trolleme, belirgin bir araçsal amaç olmaksızın internette sosyal bir ortamda aldatıcı, yıkıcı ya da parçalayıcı biçimlerde davranma pratiğidir. Belirli bir perspektiften bakıldığında internet trollerinin, klasik Joker kötü adam karakteriyle birçok özellik taşıdı̆̆ı görülebilir. Bu yönüyle troller, internet üzerinden kaos ajanları olarak faaliyet göstererek, kullanıcılara bir şekilde aşırı duygusal ya da

5 Kodlayıcılar tarafından kişisel bilgisayarları yedekleyip güncellemek için basit kod dizileri ve Twitter'daki sosyal odaklı, otomatikleşmiş, etkileyici hesaplar olan botların oluşturduğu botnet ise, virüs bulaşmış özel bilgisayarların, hizmet dışı bırakma ya da hizmet reddi başlatması (DDos) saldırıları gibi görevler için tercih edilen ağlar olarak adlandırılır. Genellikle, her dügümün otomatik görevleri gerçekleştiren bir programı barındıran makinelerin ağını ifade etmektedir (Howard vd., 2018: 82-83).

6 Türkiye'de yaygın olmamakla birlikte, kullanıcılar tarafından içeriklerin yüklenebildiği ve aynı zamanda bağlantı paylaşabildiği, paylaşılan içeriklerin oylanabildiği sosyal haber sitesidir.

7 AstroTurf, "belirli bir ürün, politika ya da olay için kendiliğinden gelişen taban desteğinin olduğunu göstermek için aktörlerin ödediği politika ve reklamcılıkta kullanılan bir PR (halkla ilişkiler) tekniği” (Han, 2015: 109) biçiminde tanımlanabilir. Bir seçim zaferi elde etme ya da bir yasama için destek arama sürecidir. Bu doğrultuda, siyasal aktörlerin kendilerine sempati duyacak bir seçmen kesimi bulmalarını sağlayabilmeleri ve bu kesimleri harekete geçirebilmeleri amaçlanır. Bu, hiçbir yerde olmayan kamuoyunun fikir birliği imajın oluşturmak için bireysel insan aktörlerin çevrimiçi ortamlarda siyasal görevler yapmak için robotları oluşturmasıdır. Bu algoritmalar, seçilmiş yetkililerin daha popüler görünmesini sağlamak amacıyla politikacıları takip etmek ve desteklemek, belirli meseleleri ve insanları destekleyen ya da onlara karşı propaganda yapmak amacıyla tasarlanırlar. Diğer durumlarda, bir AstroTurf kampanyasında aktif vatandaşlar için girişimlerde bulunarak çevrimiçi aktivistlere binlerce tweet göndermek ya da makul değiş tokuşu yapmak için kullanılabilirler (Howard vd., 2018: 86). 
aptalca görünmelerine neden olabilirler. Kullanıcılar, "trolleme" olarak adlandırılan bu tip tuzaklara düşmeleri durumunda, daha yoğun, acımasız bir eğlence anlayışına doğru sürülebilirler (Buckels vd., 2014: 97).

İnternette tartışmalara yol açarak ya da insanları kışkırtıcı yorumlar göndererek rahatsız eden kişileri işaret etmek için kullanılan "trol" kavramı, eğlencelik olmaktan çıkarak siyasal karaktere bürünmüştür. Rusya'da bir dizi internet yasası ve merkezlerin dijital gündemlere müdahale eden trollere ev sahipliği yapması için merkezi bir siyasal trol yapısı bulunur. Rus hükümetine bağlı devlet destekli anonim internet siyasal yorumcuları ve trolleri, "trol ordusu" ve "web tugayları" olarak adlandırılmaktadır (Saka, 2018: 163). Benzer biçimde çeşitli kesimlerce trollerin kullanımı da Türkiye'de yadsınamaz bir olgudur. Her ne kadar siyasal aktörlerce kimi zaman inkâr edilmesine kimi zaman ise benimsenmesine karşın, yaygın biçimde sosyal medyada siyasal amaçları yerine getirmeleri söz konusu olabilmektedir. ${ }^{8}$

Ancak, yukarıdaki türlerden hangisinin daha yoğunluklu kullanıldığının bilişimsel propaganda için pek de bir önemi bulunmamaktadır. Gerek algoritma tabanlı bot hesapları gerek program destekli insan hesaplar gerekse gönüllü ya da ücret ödenen görevli kişilerden oluşan insan hesapların propaganda amaçlı giriştikleri tüm etkinliklerinin belirlenmesi gerekir. Bir siyasal kampanya sürecinde hepsinin ya da bir kısmının çalışıyor olmasının, bir kısmının diğerlerine göre daha aktif olmasının, trol, bot hesaplarının tek tek incelenmesinin pek önemi yoktur; önemli olan sonuçtur. 'Vakanın oluş şekli' ya da bir diğer deyişle 'failin yöntemi' (modus operandi), yapılacak araştırmada kimin yarar sağladığını ortaya koyabilir.

\section{Araştırma Deseni ve Yöntem}

Dijital iletişimsel pratiklerin izlenmesinde ve çözümlemelerin yapılmasında Twitter'ın uygun sosyal medya platformu olarak tanımlanmıştır. Howard vd.'nin (2018) dikkat çektiği gibi, bir sosyal botun Twitter'da nasıl çalıştığını anlamak için öncelikle yüksek oranda otomatikleştirilmiş sosyal medya hesaplarının davranışını yöneten algoritmaların kavramsal mimarisini anlaşılması gerekmektedir. Bu aşamada bir yazılım (kodlama) parçasının akıllı bir araç olup olmadığı anlamak için, eldeki yazılımın bir aracı mı yoksa sadece bir program mı olduğu sorulmalıdır. Akıllı ajanlar, belirli hedeflere ulaşmak için belirli bir hesaplama ortamını gözlemlemek ve hareket etmek üzere özel olarak tasarlanmışlardır. Bu kodlanmış ajanlar, değişen ve dolayısıyla öngörülemeyen ortamlarda gezinebilirler ve bunları etkileyebilirler. Daha basitçe söylemek gerekirse, akıllı ajanlar insan kullanıcıları adına çalışır, bilgiyi ayrıştırır ve belirli bir sonuca karar verirler. Birçok sosyal ve siyasal bot, akıllı aracılar olarak görülebilir: Belirli zamanlarda kullanıcı adına tweet ya da retweet atmak için tasarlanan algoritmalar gibi diğer otomatik komut dosyaları, akıllı aracıları tanımlayan bu mantıksal özellik koleksiyonuna sahip değildirler. Algoritmayla oluşturulmuş siyasal içeriği bilgilendiren veriler genellikle

8 Örneğin AKP MKYK üyesi Prof. Dr. Edibe Sözen kendi Twitter hesabından açıklama yaparak, "AKTroller ülkesini, milletini seven bir gençliktir" derken, dönemin Başbakanı Ahmet Davutoğlu'nun denetimsizliklerinden rahatsız olduğu, "parti içinde artık 3-5 kendini bilmez seviyesiz trollerin küfürlerine son verilmeli" tepkilerinin olduğu basına yansımıştır (Hürriyet, 1 Eylül 2015). 
medya özellikleri, organizasyon biçimleri ve uluslararası sınırlardan gelen kişisel kayıtların kapsamlı bir şekilde çıkarılmasından kaynaklanmaktadır (Howard vd., 2018: 85). Bu ayrım, araştırma bulgularının değerlendirilmesinde, eldeki verilerin bir algoritma temelli bot mu yoksa program kullanan bir insan (trol) olduğunun anlaşılmasını sağlar.

Türkiye'de siyasal iletişim alanında sosyal medya üzerine kısıtlı da olsa çalışmalar söz konusudur. Bu çalışmalarda Türkiye'nin, siyasal amaçlarla kullanılan trollere (Harris, 2016) ve robotsal lobicilik taktiklere (Forelle, Howard, Monroy-Hernández, \& Savage, 2015) sahip ülkeler ${ }^{9}$ arasında olduğu belirtilmektedir. En çok bot nüfusa sahip olan ülkeler arasında sayılan Türkiye, kimi kaynağa göre dördünc $\ddot{u}^{10}$ sırada (Symantec Corporotion, 2018), kimi kaynağa göre altıncı sırada (Spamhaus, 2018) yer almaktadır. Türkiye'de siyasi trollük (Saka, 2016) (Bradshaw ve Howard, 2017) ve troller (Saka, 2018) üzerine çalışmalar söz konusu olmasına karşın, bilişimsel propagandaya, dolayısıyla da botlara yönelik belirgin bir araştırmaya rastlanmamaktadır.

Bu boşluk, Türkiye'de siyasal bot kullanımının belirlenmesinin önemli olduğuna işaret etmektedir. Bu çalışmada, güncel bir olay olarak 23 Haziran İstanbul Büyükşehir Belediye Seçimleri kapsamında yürütülen sosyal medya platformu olarak Twitter üzerinden otomatik etkinlikler incelenmiştir. Yenilenen 23 Haziran 2019 İstanbul Belediye Başkanlığı Seçimleri'ne Saadet Partisi (SP) ve Vatan Partisi (VP) dişında Adalet ve Kalkınma Partisi (AKP) ve Milliyetçi Hareket Partisi'nin (MHP) oluşturdukları Cumhur İttifakı ile Cumhuriyet Halk Partisi (CHP) ve İyi Parti'nin (İP) oluşturdukları Millet İttifakı'nın adayları girmişlerdir. Seçimlerde dört aday olmasına karşın, iptal edilen seçime bakılarak seçilme olasılığ 1 en yüksek iki aday araştırma konusu edilmiştir. Cumhur İttifakı adayı Binali Yıldırım'ın ve Millet İttifakı adayı Ekrem İmamoğlu'nun ve bağlı oldukları ittifakların kullandıkları hashtagler'den en çok kullanılanlar seçim kampanyalarının en yoğun olduğu seçim haftası analiz sürecine sokulmuştur.

Verilerin toplanması, çeşitli araçlar kullanılarak gerçekleştirilmiştir. İstanbul için yenilenen 23 Haziran 2019 Yerel Seçimleri'ne katılanlardan Yıldırım ve İmamoğlu'nun Twitter hesaplarının takipçi sayıları ikincil veri olarak düşünülmüştür. Elde edilen bot ve diğer bilişimsel propaganda araçları verisine katkı yapması için bu adayların takipçi sayıları 30 Mayıs-23 Haziran 2019 tarihi itibariyle manüel olarak izlemeye alınmıştır. Böylece günün belirli saatlerindeki takipçi sayılarındaki değişim (artış ya da azalış) belirlenebilmiştir.

Adayların takipçileri içinde otomatikleşmiş insan olmayan hesap olup olmadığ sorgulanmıştır. Twitter'da hashtag içeren paylaşımda bulunmak için kullanılan araçların yanı sıra, Twitonomy aracılığıyla farklı bir örneklem üzerinden adayların

\footnotetext{
9 Bot kullanan ülkeler, Rusya, Meksika, Çin, Avustralya, Birleşik Krallık, ABD, Azerbaycan, İran, Bahreyn, Güney Kore, Türkiye, Suudi Arabistan ve Fas olarak sıralanabilir (Forelle vd., 2015: 6). Sözü edilen ülkelerin çeşitli yönetim biçimlerinde ve demokratikleşme seviyelerinde olduğu gözlemlenmektedir.

10 Symantec şirketinin Norton Bölümü'ne göre 25 Haziran 2017 tarihinde Türkiye, Avrupa toplam bot nüfusunun \%8,46'sına ev sahipliği yaparak 38 ülke içinde, Rusya, İtalya ve Almanya'nın ardından dördüncü sırada yer almaktadır. Bot nüfusunun en çok olduğu şehirler sıralamasında ise İstanbul \% 4,62 ile Madrid'in $(\% 4,64)$ ardından, bot kullanımıyla ünlenen Moskova’yı (\% 4.59) bile geçerek ikinci, Ankara $(\% 1,85)$ ise onuncu sıradadır. Türkiye'de bot nüfusunun en çok olduğu şehir İstanbul (\% 54,59), Ankara (\% 21,85), İzmir (2,82), Adana (2.39) ve Bursa (1.42) olarak sıralanmaktadır. Araştırmada, Vatikan'da bile her 5 internet kullanıcısına 1 bot düşerken, Türkiye'deki bu sayı 30 kişi olarak belirlenmiştir.
} 
takipçilerinin tweetler, takipçiler ve arkadaşları, günlük tweet ortalamalarına ulaşılmış yani otomatikleşmiş siyasal trafiğin ritmi ${ }^{11}$ olup olmadığına bakılmıştır. Ayrıca adayların takipçileri içinde içerik üretiminin dağıtımını anlamak için katkı yapan toplam nüfusun segmentine (bölümü oluşturan parçalara) de bakılmıştır. ${ }^{12} \mathrm{Bu}$ aşamada, sıfır ya da sıfıra yakın paylaşımları olan hareketsiz (hayalet) hesaplar da göz önünde bulundurulmuştur.

Adayların hashtagler'inin diğer kullanıcılar tarafindan hangi kaynaklardan dolaşıma sokulduğu Twitter API üzerinden çalışan GitHub TCAT adlı açık kaynak yazılımıyla gerçekleşmiştir. ${ }^{13}$ Böylece adayların takipçilerden günlük tweet ortalaması en çok ikişer aday belirlenmiş ve seçim tarihinden üç gün önce (20 Haziran 2019) açık kaynaklı bir ağ analizi ve görselleştirme yazılımı olan Gephi ile etkinlikleri belirlenmeye çalışılmıştır.

Amaç, adayların günlük takipçi sayılarındaki değişimi ve günlük tweet ortalamalarını, takipçilerin giriş yaptıkları kaynak platformları, oluşturulan hashtagler'in (sanal yol izleri) ya da sözcüklerin (anahtar sözcükler) kullanım sıklığını, yoğun paylaşımda bulunan hesapların kime ait oldukları ve bunların kimler adına etkinliğe giriştiklerini belirlemek olmuştur. Çünkü sosyal medya pazarlaması tümüyle etkileşim (engagement) ile ilgilidir ve etkileşim marka için daha yüksek görünürlük sağlamakla birlikte, hashtag içeren tweetler'in yaygın kullanımı ${ }^{14}$ söz konusudur (Dominique, 2017).

$\boldsymbol{H}-1$ Adayların takipçileri arasında bot ve cyborg (tam ve yarı otomatik) hesapları aktif olarak kullanılmakla birlikte, aktif kullanıcılar kadar hareketsiz duran bot karakterli hesaplar da bulunmaktadir.

$\boldsymbol{H - 2}$ Adayların sosyal medya hesaplarının takipçileri içinde trollerin ve botların (dijital etki çarpanları) katkıları normal hesapların katkılarından daha çoktur.

H-3 Adayların takipçileri arasında bot, cyborg gibi tam ya da yarı otomatikleşmiş hesaplar vardır ve adayların çıkarları doğrultusunda etkinlikte bulunmaktadırlar.

Genelde Türkiye'de troller üzerine yapılan araştırmalar kadar her geçen gün yaygınlaşan bilişimsel propagandanın önemli unsuru olan botların da belirlenmesi gerekmektedir. Aşağıdaki sorular yanıtlamaya çalışılmaktadır:

$\boldsymbol{A S} \mathbf{S} \mathbf{1}$ Bot ve otomasyon hesapları adaylara olumlu katkı yapacak biçimde Twitter trafiğinde ne kadar yoğunlukta bulunmaktadır?

$\boldsymbol{A S}$-2 Siyasi partilerin sosyal medya üzerinden siyasal kampanyalarında dijital etki çarpanı söz konusu mudur; söz konusu ise her parti ve aday için yoğunlukları ne kadardır?

11 Otomatikleşmiş siyasal trafik, yüksek otomatikleşmiş hesaplar arasında üretilmiş hashtagler üzerinde açıkça tutarlı bir trafik oranı olup olmadığına bakılarak bulunabilir. Tipik insan kullanıcılar, günlük 50 gönderiye kadar, trol olarak tabir edilen gerçek kişiler 50-100 gönderiye kadar, cyborglar 100-200 arası gönderi ve propaganda botları 200 üstü gönderi yapan hesaplar olarak tanımlanmıştır (Kollanyi vd., 2016).

12 Otomasyon gözlemi, insan kullanıcılar ile bot hesaplar arasında dikkat çekici farklılıklar olduğu önvarsayımı (Kollanyi vd. 2016) göz önünde bulundurulur.

13 Sosyal medya çözümlemesi yapabilen çok sayıda API bulunmaktadır. Araştırmaların niteliğine göre bunlar arasından seçim yapılabilmektedir. Öne çıkan örnekler, tüm Twitter etkinliklere yönelik Twitonomy; bot ve otomasyon çözümlemelerinde Streaming API, Tweepy (Phyton) API, GitHub TCAT API; Twitter etkinliklerini harita üzerinde gösteren Dataminr, Geofedia; verilerin görselleştirmesini yapan Trendalyzer gibi yazılımlardır. 14 Hashtagler'in etkileşimi (likes+retweet) yönlendirdiği söylenebilir: Hashtagler, sosyal medya siteleri ve kullanıcılarının içeriklerinin sınıflandırılmaları ve konuların daha açık anlaşılabilmesi için kullanılır; bu yararları, hashtaglı tweet'ler iki kat etkileşim ve \% 50 oranında daha çok retweet sağlayabilmesi (Dominique, 2017) nedeniyle önemlidir. 
$\boldsymbol{A S}$-3 Hangi siyasi partilerin ya da adayların takipçileri yoğunluklu olarak bot/trol etkinlikleri gerçekleştirmektedir?

$\boldsymbol{A S}$-4 En çok paylaşımda bulundukları belirlenen hesaplar bot ya da cyborg mudur; öyle iseler türleri (takipçi, barikat, propaganda) nelerdir?

Kısacası, amaca uygun olarak araştırma, Twitter trafiğinin ritmi, tam ya da yarı otomatikleşmiş siyasal trafiğin izlenmesi, varsa otomasyon gözlemi ve türlerinin belirlenmesini kapsamaktadır.

\section{Bulgular}

Araştırmanın sınırlılı̆̆ı çerçevesinde dört adaydan yalnızca ikisi araştırma öznesi olarak alınmıştır. Türkiye'de 2019 yılında yapılan yerel seçimlerin İstanbul için yenilenmesinde aday olan Binali Yıldırım ve Ekrem İmamoğlu'nun 30 Mayıs 2019 tarihinden itibaren Twitter hesaplarının takipçilerindeki değişim (artış/azalış) izlenmiştir (Bkz. Görsel 1).

Görsel 1. Adayların takipçi sayılarındaki ivme.

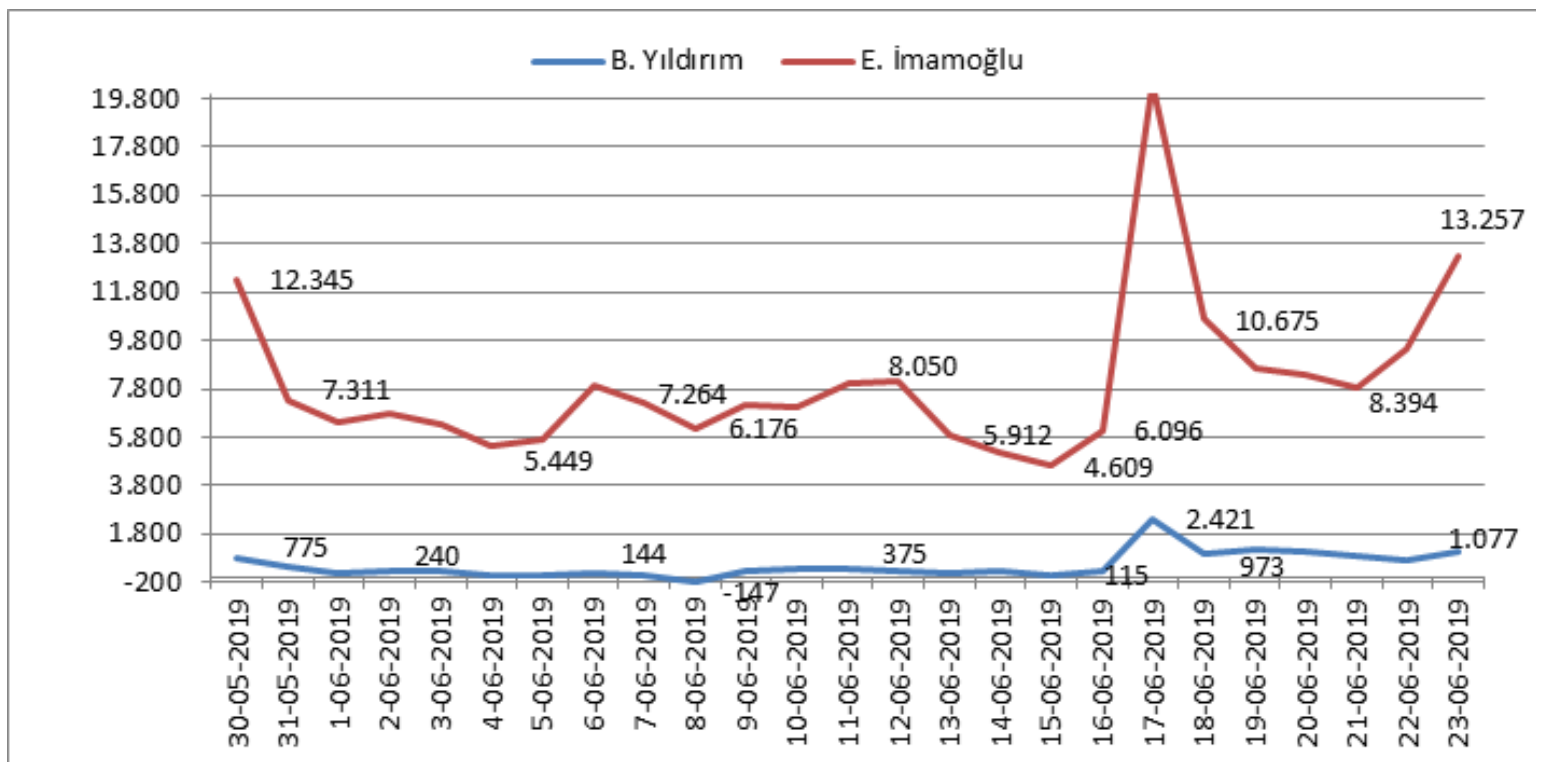

İzleme süresince hemen hemen her gün her iki adayın gece artan takipçi sayılarında saat 06.00 ve 06.30 'da düşüşler yaşanmakta olduğu belirlenmiştir. Sahte, klon ya da bot hesaplara karşı Twitter sürekli mücadele içindedir. Sisteme sızan bu türdeki uygunsuz hesaplar Twitter'ın ajan botları tarafından yakalanmakta, geçici olarak askıya alınmakta, doğrulanamaması durumunda imha edilmektedir. Özellikle gece saatlerinde açılan hesaplar sabah aynı saatlerde taranmaktadır. İncelenen zaman aralığında bot, sahte ya da klon hesapların varlığına bir işaret olarak yorumlanabilecek bu düşüşler, kimi zaman günlük değişimleri bile etkileyebilecek ölçüdedir. 
Bir sonraki aşama adayların takipçilerinin türlerinin belirlenmesi olmuştur. Adayların her biri için yaklaşık $15^{\prime}$ er bin kişilik Twitter takipçi bilgilerini içeren veri setlerine Twitonomy aracılığıyla ulaşılmıştır (Bkz. Tablo 1). Yıldırım'ın 14.998 örneklem içinde seçim kararı alındığ 6 Mayıs 2019 tarihinden itibaren yeni açılan hesap sayısı 6.040 adet $(\%$ 40,27) iken, İmamoğlu'nun ise 14.994 örneklem içinde 7.581 adet (\%50.56) olmuştur. Bu yeni hesaplar seçime yönelik ilgili olduğu, bu nedenle de daha anlamlı bulgulara ulaşılacağı ön varsayımıyla sınıflandırılmaya çalışılmıştır.

Tablo 1.Adayların takipçilerinin tweetleme sayılarına göre hesap türleri

\begin{tabular}{|c|c|c|c|}
\hline & & B. Yildırım & E. İmamoğlu \\
\hline \multirow{3}{*}{ Toplam } & Kullanıcı & 14.998 & 14.994 \\
\hline & $\%$ & 40,27 & 50,56 \\
\hline & Yeni Hesap & 6.040 & 7.581 \\
\hline \multirow{4}{*}{ Kişi (0 tweet) } & Kullanıcı & 2.330 & 5.411 \\
\hline & Takipli Kullanıcı & 1.307 & 2.278 \\
\hline & $\%$ & 56,09 & 42,10 \\
\hline & Takipçi & 6.514 & 6.242 \\
\hline \multirow{4}{*}{ Kişi (1-49 tweet) } & Kullanıcı & 3.558 & 2.155 \\
\hline & Tweet & 14.350 & 27.632 \\
\hline & Takipçi & 69.888 & 34.130 \\
\hline & Etki & 11.937 .855 & 3.954 .745 \\
\hline \multirow{4}{*}{ Trol (50-99 tweet) } & Kullanıcı & 77 & 12 \\
\hline & Tweet & 61.590 & 5.500 \\
\hline & Takipçi & 10.299 & 672 \\
\hline & Etki & 9.752 .182 & 441.161 \\
\hline \multirow{4}{*}{ Cyborg (100-199 tweet) } & Kullanıcı & 54 & 3 \\
\hline & Tweet & 96.255 & 5.785 \\
\hline & Takipçi & 8.213 & 56 \\
\hline & Etki & 15.811 .584 & 249.391 \\
\hline \multirow{4}{*}{ Bot (200 - 999 tweet) } & Kullanıcı & 19 & 0 \\
\hline & Tweet & 39.995 & 0 \\
\hline & Takipçi & 2.937 & 0 \\
\hline & Etki & 6.353 .151 & 0 \\
\hline \multirow{4}{*}{ Bot $(1.000+$ tweet $)$} & Kullanıcı & 2 & 0 \\
\hline & Tweet & 15.998 & 0 \\
\hline & Takipçi & 128 & 0 \\
\hline & Etki & 1.005 .328 & 0 \\
\hline
\end{tabular}

Kimi araştırmacılar otomatikleşmiş hesapları (cyborg) botlardan farklı görmemekle (Khan ve Thakur, 2018) birlikte, kimi araştırmacılar ise hareketsiz hesapları bot olarak kabul etmektedirler. 6 Mayıs 2019 tarihinden itibaren açılan hesaplar içinde, Yıldırım 2.330 adet $(\% 38,58)$ ve İmamoğlu'nun 5.422 adet $(\% 71,38)$ hesabın hareketsiz olduğu ve Yıldırım'ın hareketsiz takipçileri içinde \%56,09 ve İmamoğlu'nun ise, \%2,10 oranında arkadaşsız (takipçisiz) oldukları anlaşılmaktadır. Bu kategoriye giren hesapların takipçi botlar olarak sinıflandırılabilir. 
Günlük ortalama 1 ile 49 adet tweet gönderen hesaplara bakıldığında hareketsiz hesaplardan daha az oldukları görülmektedir. Yıldırım'ı takip eden 3.558 adet hesabın ve İmamoğlu'nu takip eden 2.155 adet hesabın gerçek kişi hesap olarak sınıflandırılmıştır. İmamoğlu'nun (27.632 tweet) takipçi hesaplarının daha aktif olmalarına karşın, etkilerinin (3.954.745 etki) daha düşük oldukları anlaşılmaktadır.

Araştırmanın asıl ilgi odağı olan otomatikleşmiş hesaplara bakıldığında ise aktiflikte benzer bulgulara rastlanabilmektedir. Yıldırım'ın takipçileri arasında günde 50 ile 100 arasında tweet atabilen (77 adet) hesaplar, İmamoğlu'nun (12 adet) takipçilerinden daha çoktur ve kaçınılmaz olarak bu hesapların ulaşabildikleri hesapların daha çok olmaları nedeniyle etkileri daha büyüktür. Benzer biçimde, günde ortalama 100-200 arasında tweet atan cyborg olarak sınıflandırılan Yıldırım'ı takip eden (54 adet) hesaplar, İmamoğlu'nun (3 adet) takipçilerinden sayıca ve yine etki açısından daha çoktur.

Twitter'da kişi ve kurumları takip etmek ya da paylaşımda bulunmak amacıyla kendi uygulaması (Twitter API) dışında çeşitli programlardan yararlanılabilir. Üçüncü kişi yazılımları olarak da adlandırılan çeşitli programlar kullanıcıların etkinlikte bulunmalarını kolaylaştırıcı işlevlere sahiptirler. Gerek web üzerinden gerekse Google Play benzeri platformlardan (1) otomatik olarak gönderim; (2) otomatik postaların/ içeriklerin programlanması; (3) sosyo-dijital ağda yer alan kullanıcının tüm arkadaşlarını tek içerikle (posta, tweet, link, fotoğraf) etiketlenmesi; (4) aynı içeriğin/mesajın yüzlerce kez tekrar gönderilmesi; (5) özel mesajlar biçiminde spam gönderilmesi; (6) aynı/benzer hesapların tüm gönderileri için otomatik beğenmelerin/takiplerin alınması; benzer kamuya açık sayfalara otomatik beğeni yapılması/takip edilmesi; (8) kitlesel hesaplar/gruplar ekleyerek çok sayıda arkadaşlar/takipçi edinilmesi gibi işlevlerle çeşitli programlara erişilebilmekte ya da otomatikleşmiş işlemler için hizmet satın alımı yapılabilmektedir (Lanford ve Sued, 2017).

Söz konusu uygulamalar çok yaygın olarak çeşitli amaçlarla kullanılabilmektedir. Hiperweetleme genellikle bir hesabın bir bot olduğunun iyi bir göstergesidir; ancak, belirli bir mesajı yaymak için kurulmuş politik bir bot olduğunu belirtmek zorunda değildir. Birçok kuruluş, görevlerini otomatikleştirmek için botlar kullanmaktadırlar (Nimmo, 2016). Çeşitli araştırmalarda, en çok otomasyon uygulamalarının IFTTT (IF ThisThenThat), Myretweet, Botize, Plume, Tweetbot olduğu bulgulanmıştır (Lanford ve Sued, 2017). Bireysel kullanıc1lar, bu programların yanı sira, TweetDeck ve HootSuite (Nimmo, 2016), TweetCaster (Lanford ve Sued, 2017), Buffer (Khan ve Thakur, 2018) gibi çevrimiçi araçlar yardımıyla bot gibi otomatikleşebilmektedirler.

17-24 Haziran 2019 tarihleri arasında adayların hashtagler'ini kullanan hesapların giriş yaptıkları kaynaklar TCAT ile farklı örneklemler üzerinden aşağıdaki gibi (Bkz. Tablo 2) belirlenmiştir. Yıldırım'a ait olan \#yaparsaakpartiyapar ve \#yinebizyaparız hashtagler'i ile İmamoğlu'na ait\#İmamoğluvarsaÇözümvarve\#HerŞeyÇokGüzelOlacak hashtagler'i izlenmiştir. ${ }^{15}$

Twitonomy tarafından TwitterAPI'den çekilen örneklem içinde Yıldırım'ın takipçileri arasında paylaşımda bulunan cyborg ve bot yeteneğine sahip hesaplara

15 Adayların, partilerin ve ittifakların diğer hastagler'i için ayrıca bkz. Ek-2 
rastlanmıştır. Ancak bu kez, hashtag kullanan kullanıcılar incelendiğinde, Yıldırım'a aite \#yaparsaakpartiyapar ve \#yinebizyaparız hashtagler'i kullanımında bot girişine rastlanmamış, otomasyon uygulamaları ise düşük düzeyde kalmıştır. Benzer biçimde İmamoğlu'na ait \#İmamoğluvarsaÇözümvar hashtag'i kullanan ne otomasyon ne de bot girişine rastlanmamıştır. Ancak, yine İmamoğlu'na ait olan \#HerŞeyÇokGüzelOlacak hashtag'i kullanan kullanıcıların hem bot hem de otomasyon girişleri söz konusu olmuştur.

Tablo 2. Takipçilerin hashtag kullanımlarında giriş yaptıkları kaynaklar

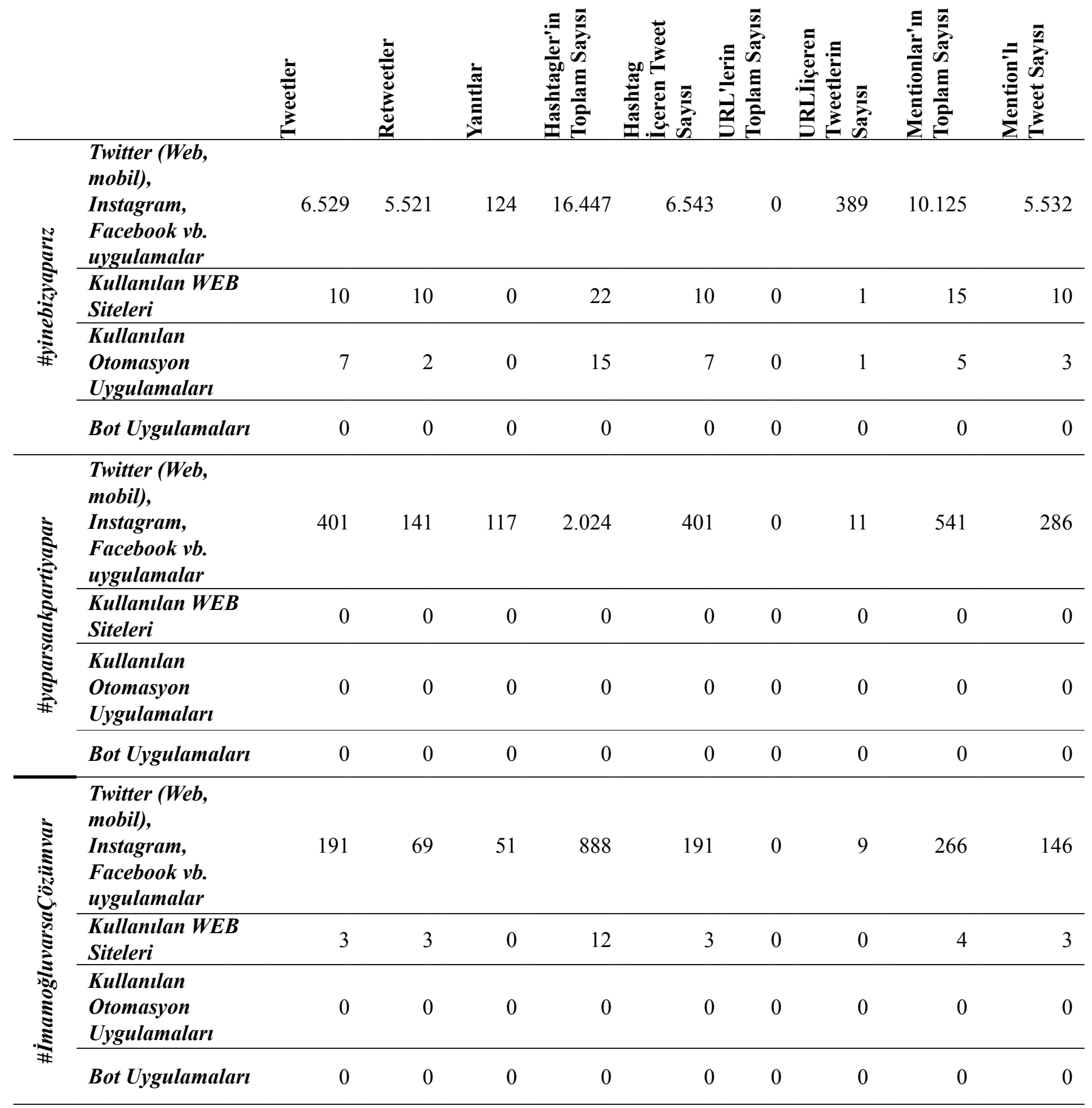




\begin{tabular}{|c|c|c|c|c|c|c|c|c|c|c|}
\hline \multirow{4}{*}{ 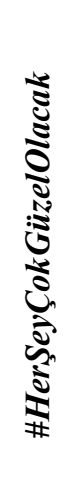 } & $\begin{array}{l}\text { Twitter (Web, } \\
\text { mobil), } \\
\text { Instagram, vb. } \\
\text { uygulamalar }\end{array}$ & 147.645 & 95.582 & 18.298 & 233.457 & 147.628 & 0 & 38.786 & 148.019 & 118.518 \\
\hline & $\begin{array}{l}\text { Kullanilan WEB } \\
\text { Siteleri }\end{array}$ & 244 & 237 & 0 & 509 & 244 & 0 & 42 & 287 & 237 \\
\hline & $\begin{array}{l}\text { Kullanulan } \\
\text { Otomasyon } \\
\text { Uygulamalart }\end{array}$ & 249 & 142 & 5 & 564 & 249 & 0 & 41 & 245 & 177 \\
\hline & Bot Uygulamalart & 1 & 319 & 1 & 25 & 319 & 318 & 0 & 1 & 1 \\
\hline
\end{tabular}

İnsanüstü bir güçle günde ortalama 200 ve üstü tweet atabilen çok sayıda hesaplara rastlanmıştır. Yıldırım'ın takipçileri arasında bot statüsüne girebilecek takipçiler (23 adet) bulunmaktadır. Ancak, hesap açtıkları tarihten 20 Haziran 2019 tarihine kadar paylaşımda bulundukları özellikle iki adet hesap günde ortalama 1.000 tweet'ten daha çok gönderi yapabilme yeteneğine sahiptir (Tablo 3). Aynı gün (18 Haziran 2019) aktif hale gelen ve kendilerini, "6000 sayılı kanun 26 madde mağdurları"16 olarak nitelendiren bu iki hesaptan biri olan $\boldsymbol{B}-1$, ilk hesaplama tarihi olan 20 Haziran 2019'a kadar günde ortalama 1.410 adet, diğeri $\boldsymbol{B}-2$ ise ortalama 960 adet tweet atabilmektedir. İmamoğlu'nun takipçileri arasında da 200 ve üstü tweet atan iki hesaba rastlanmıştır. Açıldıkları tarihten yine 20 Haziran 2019 tarihine kadar en aktif olan 4B sözleşmelilerin mağduriyetlerini gündeme taşıyan hesaplardan biri olan $\boldsymbol{E}$-1, yine ilk hesaplama tarihi olan 20 Haziran 2019'a kadar günde ortalama 304 adet tweet atabilmesine karşın, sonradan hesabı askıya alınmıştır. Eşit ceza indirimi isteyen diğer hesap $\boldsymbol{E}-2$ ise günde ortalama 297 adet tweet atmaktadır.

Tablo 3. Adayların en yüksek paylaşım yapan takipçileri ile ilgili veriler

\begin{tabular}{|c|c|c|c|c|c|c|c|c|c|c|}
\hline$\frac{3}{2}$ & Hesap & $\begin{array}{l}\text { Hesap } \\
\text { Açılışı }\end{array}$ & $\begin{array}{c}\text { İlk } \\
\text { Hesaplama }\end{array}$ & Gün & $\begin{array}{c}\text { Toplam } \\
\text { Tweet }\end{array}$ & $\begin{array}{c}\text { Ortalama } \\
\text { Tweet }\end{array}$ & $\begin{array}{c}\text { Son } \\
\text { Hesaplama }\end{array}$ & Gün & $\begin{array}{c}\text { Toplam } \\
\text { Tweet }\end{array}$ & $\begin{array}{c}\text { Ortalama } \\
\text { Tweet }\end{array}$ \\
\hline$\Xi$ & $B-1$ & 18.06 .2019 & 20.06 .2019 & 3 & 4.231 & $1.410,33$ & 23.06 .2019 & 6 & 9.335 & $1.555,83$ \\
\hline 글 & $B-2$ & 18.06.2019 & 20.06 .2019 & 3 & 2.881 & 960,33 & 23.06 .2019 & 6 & 6.463 & $1.077,17$ \\
\hline$\frac{1}{1000}$ & $E-1$ & 20.06 .2019 & 20.06.2019 & 1 & 304 & 304,00 & 23.06 .2019 & 4 & \multicolumn{2}{|c|}{ Askıya Alınan Hesap } \\
\hline . & $E-2$ & 19.06 .2019 & 20.06 .2019 & 2 & 595 & 297,50 & 23.06 .2019 & 5 & 1.956 & 391,20 \\
\hline
\end{tabular}

Yüksek tweet skorlarına sahip bu hesapların seçim günündeki durumları daha dikkat çekici olmuştur. Her hesabın tweet aktivitesinde yükselme belirlenmiştir. Günlük tweet ortalamalarında; $\boldsymbol{B}-1,1.555$ tweet ve $\boldsymbol{B}-2,1077$ tweet; $\boldsymbol{E}-2,391$ tweet'e kadar çıkabilmiştir. $\boldsymbol{E}-1$ ise, Twitter tarafından hesabın askıya alındığı belirlenmiştir.

16 Söz konusu madde, Türk Silahlı Kuvvetleri'nde (TSK) görev yaptıktan sonra yasadaki yaş sınırı nedeniyle sivil memurluğa geçirilip, sivil memur statüsünde emekli edilen kişilerle ilgilidir. 
Her iki belediye başkan adayının bot ya da cyborg olduğundan şüphe duyulan yukarıdaki ikişer takipçisinin ilişkiler ağı da çıkarılmıştır. İlişkiler ağı, Gephi ağ haritalama aracı kullanılarak kuvvet yönlendirmeli (ForceAtlas) ve çoklu çekim (multigravity) yöntemleriyle yapılmıştır. Yıldırım'ın takipçileri içinde en çok paylaşım yapan iki hesabın, $\boldsymbol{B}$-1 ve $\boldsymbol{B}$-2'nin, Türkiye'nin gündemini oluşturan seçimler dışında paylaşım yapmaları dikkat çekmektedir (Bkz. Görsel 2). Kırmızı noktalar etkileşime girilen düğüm (nodes) olarak adlandırılan hesapları, yeşil noktalar paylaşımları, kırmızı çizgiler ise bağlantıları (edges) göstermektedir.

\section{Görsel 2. B-1 ve B-2 kullanıcılarının ağ haritaları}
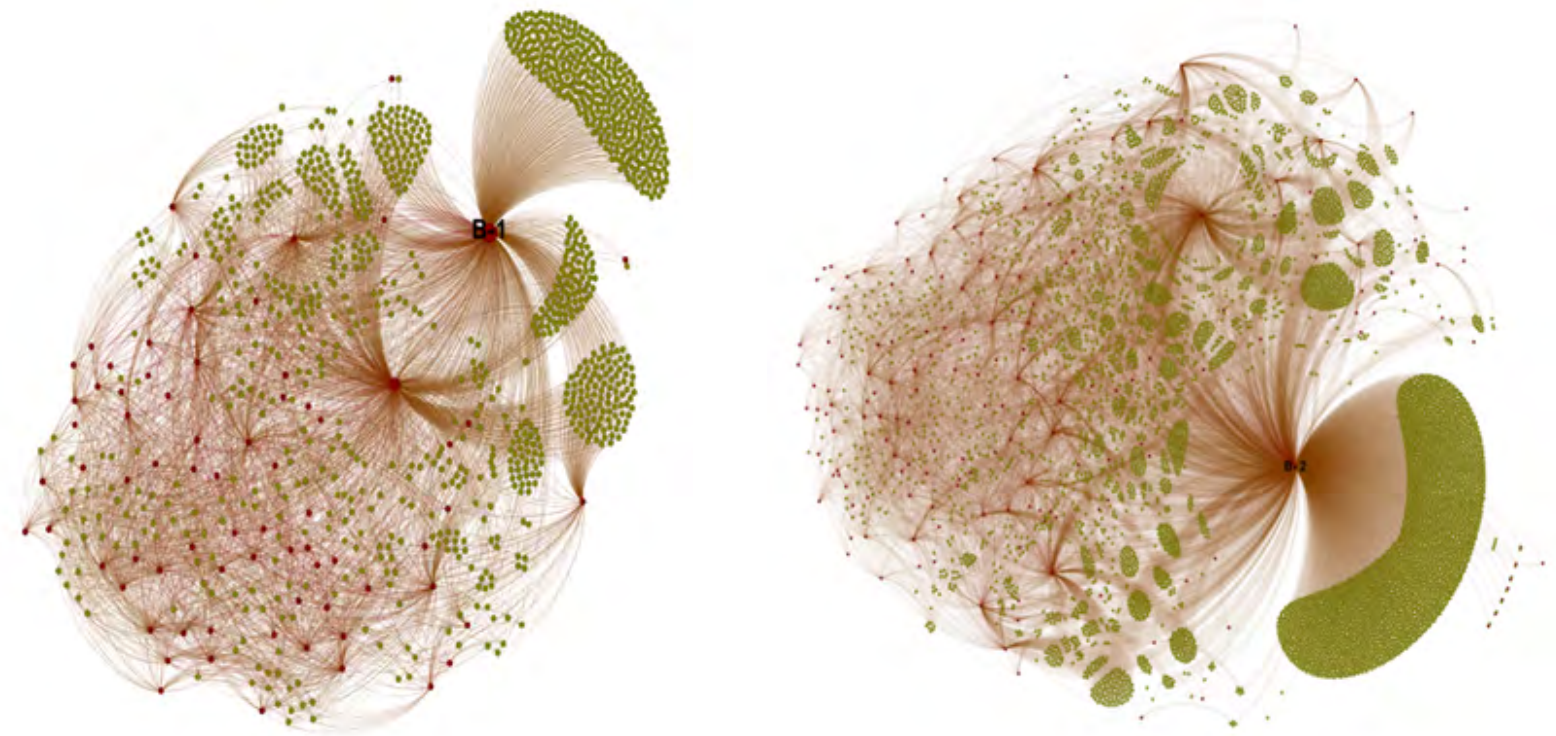

Her iki hesap da insanüstü beceriyle 6000 Sayılı Yasa ${ }^{17}$ ile ilgili paylaşımlarda bulunarak Twitter trafiği içinde kendi gündemlerini oluşturmaya çalıştıkları anlaşılmaktır. Haritalar incelendiğinde ürettikleri tweetler'in bir kısmının diğer kullanıcılarla hiçbir biçimde etkileşime girmediği görülmesine karşın, oluşturdukları gündemle göreceli olarak çok sayıda kişiyi çevrelerine topladıkları anlaşılmaktadır. Örneğin 547 takipçisi olan $\boldsymbol{B}$-1, 65 kişiyi takip ederken çevresiyle giriştiği etkinlik sayısı 4.933 olmuştur. Benzer biçimde 70 takipçisi olan $\boldsymbol{B}-2$ ise, 643 kişiyi takip etmiş ve çevresiyle 19.464 etkinliğe girmiştir.

Benzer durum İmamoğlu'nun en çok paylaşımda bulunan iki takipçisi, $\boldsymbol{E}-1$ ve $\boldsymbol{E}-2$ için de geçerlidir. Bu hesaplardan $\boldsymbol{E}-1$ eşit ceza indirimine ${ }^{18}$ yönelik paylaşımlarda

1730 Haziran 2010 yılında çıkarılan “Askeri Mahkemeler Kuruluşu Ve Yargılama Usulü Kanunu İle Bazı Kanun Ve Kanun Hükmünde Kararnamelerde Değişiklik Yapılmasına Dair Kanun”. Türk Silahlı Kuvvetleri’nde (TSK) görev yapan uzman erbaşların çıkarılan yasada belirtilen yaş sınırı nedeniyle sivil memurluğa geçirilen ve buradan da emekli edilen kişiler, özlük haklarını geri alabilmek için örgütsüz çıkar grupları gibi çeşitli girişimlerde bulunmaktadırlar.

18 Mahkum yakınlarının eşit ceza indirimine yönelik çıkmasını talep ettikleri Ceza İndirimi Yasası. Mahkum yakınları 23 Haziran 2019 Yerel Seçimleri öncesi Cumhur İttifakı adayı Bianli Yıldırım'1 destekleyecekleri açıklamışlardır (Ülkücü Medya, 226 Nisan 2019). 
bulunurken $\boldsymbol{E}-2$ ise $4 /$ b sözleşmeli personelin mağduriyetine ${ }^{19}$ yönelik paylaşımlarda bulunmaktadırlar (Bkz. Görsel 3).

\section{Görsel 3. E-1 ve E-2 kullanıcılarının ă̆ haritaları}
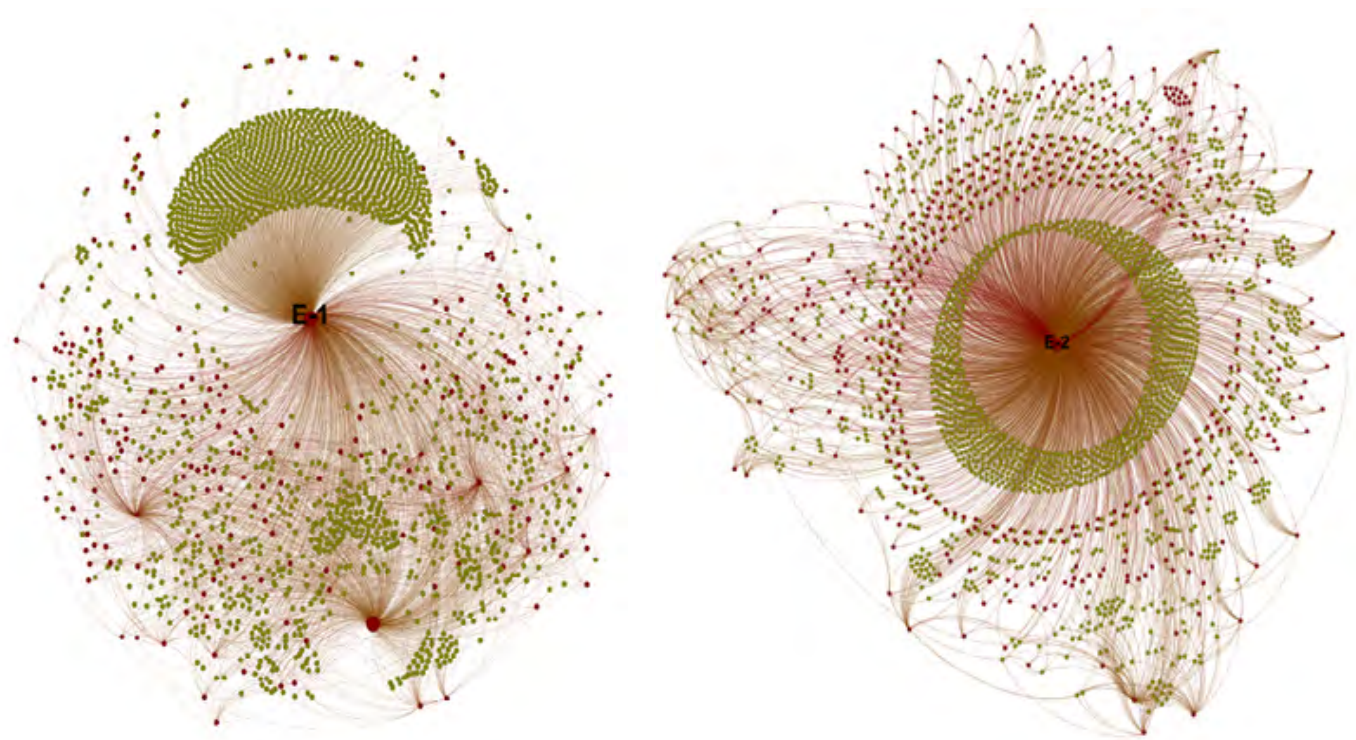

Farklı konularda da olsa her iki hesabın bir kısım paylașımları diğer kullanıcılarla etkileşime girememiştir. Diğer paylaşımların ise, kendi gündemlerini insanlara ulaştırabildikleri anlaşılmaktadır. Örneğin, 177 takipçisi olan $\boldsymbol{E}$-1, çevresiyle 4.667 etkinliğe girerken yalnızca 12 takipçisi olan $\boldsymbol{E}$-2, 22 kişiyi takip etmesine karşın çevresiyle 3.294 etkinliğe girebilmiştir.

Dört kullanıcının oluşturdukları ilişkiler birleştirildiğinde daha anlamlı bir harita ile karşılaşılmaktadır. Bu karşılaştırmaya olanak veren haritaya bakıldığında, Türkiye' de seçim atmosferinin en yoğun yaşandığ 1 günlerde seçime giren adayların takipçilerini kendi gündem konularıyla meşgul ettikleri biçimde yorumlanabilir (Bkz. Görsel 4).

19 Kamu kuruluşlarında sözleşmeli personelin çalışma durumuyla ilgili olarak 657 sayılı Devlet Memurları Kanunun 4/B maddesidir. Yasanın ilgili maddesi nedeniyle çeşitli özlük haklarından yararlanamayan personelin oluşturduğu kamunun çeşitli girişimleri söz konusudur. Sosyal medyada düşüncelerini yaymaya çalışmak bu girişimlerden biridir. 
Görsel 4. Adayların ve şüpheli hesapların gösterildiği bütünleşik ağ haritası (mavi noktalar medya dosyalarını göstermektedir)

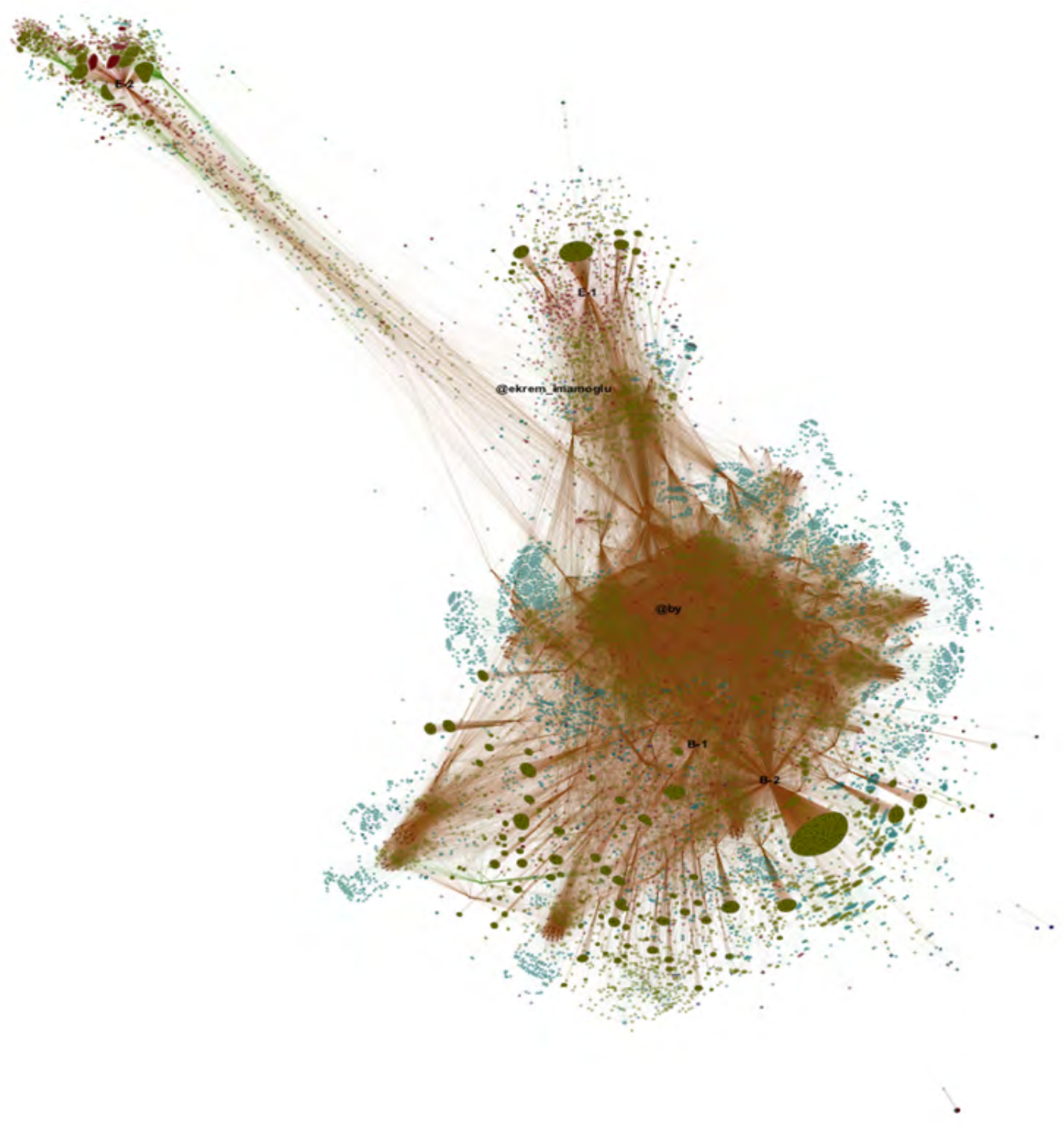

Düğümlerin büyüklükleri genel ağda içinde etkinliği/önemliliği ile doğru orantılıdır ve etrafında topladığı yeşil noktalar ise aktifliğini göstermektedir. Tüm şüpheli hesaplar kendi ağlarının merkezini oluştururken adaylara olan konumları haritada görülebilmektedir. $\boldsymbol{B}$-1 ve $\boldsymbol{B}$-2 günde ortalama 1.000 adetten daha çok paylaşım yapmaları ve aynı konuda tek hesapmış gibi davranmaları nedeniyle daha etkili oldukları görülmektedir. $\boldsymbol{B}-\boldsymbol{1}$ ve B-2 hesaplarının paylaşımları Yıldırım'ın gündemine görece yakın olduğu söylenebilir. Bu durum, $\boldsymbol{B}-1$ ve $\boldsymbol{B}-2$ paylaşımlarının merkezinde yer alan "6000 Sayılı Yasa" konusu ile Yıldırım'ın yerel seçime yönelik olan İstanbul odaklı siyasal iletişimini engellediği biçiminde yorumlanabilir. $\boldsymbol{E}-\mathbf{1}$ ve $\boldsymbol{E}-\mathbf{2}$ hesaplarının paylaşımlarının ise İmamoğlu'nun gündeminden görece daha uzak hatta tamamen ilgisiz gibi durmaktadır. $\boldsymbol{E}-1$ ve $\boldsymbol{E}-2$ 'nin paylaşım miktarlarının diğer şüpheli hesaplara göre daha az olması nedeniyle aktiviteleri ve etkileri de daha azdır ancak kendi konularında benzer soruna duyarlı kişileri kendilerine çektikleri ve merkezden uzaklaştırdıkları görülmektedir. 


\section{Sonuç}

Bu araştırmayla Türkiye'de 2019 y1lının son seçim döneminde sosyal medya aracı olan Twitter'da faaliyet gösteren algoritmik hesapların peşine düşülmüştür. 23 Haziran 2019 İstanbul Belediye Başkanlığı Seçimleri’nde aday olan adaylar içinde yenilenen seçim sonuçları göz önünde bulundurulduğunda kazanma şansı en yüksek olan iki adayın hesapları üzerinden sosyal medyanın ayrılmaz parçaları olan trol, bot ve cyborg gibi araçlar belirlenmeye çalışılmıştır. Seçimlere dört aday katılmasına karşın, kazanması en muhtemel iki ittifakın adaylarının sosyal medya faaliyetleri incelemeye alınmıştır. Adalet ve Kalkınma Partisi (AKP) ve Milliyetçi Hareket Partisi'nin (MHP) oluşturdukları Cumhur İttifakı adayı Binali Yıldırım ile Cumhuriyet Halk Partisi (CHP) ve İyi Parti'nin (IP) oluşturdukları Millet İttifakı adayı Ekrem İmamoğlu'nun Twitter hesapları, kendilerinin ve bağlı oldukları ittifakların kullandıkları hashtagler üç aşamalı olarak analiz sürecine sokulmuştur.

Adayların 30 Mayıs-23 Haziran 2019 tarihleri arasında takipçi sayıları izlenmiştir. Yapılan izlemede adayların takipçilerinde hemen hemen her gün sabah saatlerindeki anlık azalmalar yaşandığı belirlenmiştir. Söz konusu azalmaların, Twitter tarafından uygun bulunmayan, olasılıkla bot ya da trol hesapların askıya alındığı ve etkisiz hale getirildiği biçimde yorumlanmıştır. Ancak gün içerisinde yeni takipçi hesapların girişinin etkisizlerden çok olması, nüfusun sürekli artmasına neden olmaktadır. Seçimlerin ardından yapılan taramada en aktif kullanıcıların çoğunun hesaplarının askıya alındığı, bir kısmının da hesabının silindiği belirlenmiştir.

Hareketsiz hesaplar, takipçi sayısını ve listelerini şişkin göstererek bir rekabet üstünlüğü yanılsaması üretmekte, bazı hesaplar, angaje oldukları kullanıcıya yönelik eleştirileri savuşturmak için barikat kurmakta, aktif hesaplar ise çoğunlukla propaganda işlevi üstlenmektedir. Takipçilerin tamamı üzerinden yapılan seçim günü olan 23 Haziran 2019 tarihi itibariyle yapılan incelemede, "aktif kullanıcılar kadar hareketsiz duran bot karakterli hesaplar da bulunmaktadır” birinci hipotezi doğrulanmaktadır. Her iki adayın takipçilerinin \% 40-50 düzeyinde seçim döneminde açılmış hesaplardan oluştuğu; çok sayıda hareketsiz hesaplara sahip oldukları ve bu hareketsiz hesapların yine \% 40-55 düzeyinde herhangi bir takipçisinin bile olmadığ belirlenmiştir. Bu tür hesaplar takipçi bot ya da yumurta kafa (egghead) olarak nitelendirilen boş hesaplar sınıfına sokulabileceği düşünülmüştür.

Seçimden üç gün önce, 20 Haziran 2019'da, adayların takipçileri içinde otomatikleşmiş insan olmayan hesap olup olmadığı sorgulanmıştır. Twitter' da hashtag içeren paylaşımda bulunmak için kullanılan araçların yanı sıra, adayların takipçilerinin Twitonomy aracılığıyla farklı bir örneklem üzerinden tweetler, takipçiler ve arkadaşları, günlük tweet ortalamalarına ulaşılarak otomatikleşmiş siyasal trafĭgin ritmi olup olmadığına bakılmıştır. Her adayın takipçileri içinde bot ya da cyborg şüphelisi hesaplara rastlanmış; en aktif ikişer tanesi ağ analizi ve görselleştirme yazılımı olan Gephi ile takibe alınmıştır. Her adayın en çok paylaşım yapan ikişer takipçisinin ilişkiler ağı çıkarılmıştır. En çok paylaşımlar, insanüstü olarak kabul edilen günlük ortalama 200 ve üstü paylaşımı temsil eden otomatikleşmiş sınıfına girmiştir. Söz konusu hesapların durumları kısmi 
olarak üçüncü hipotezi doğrulamaktadır. Tüm hesaplar, "bot, cyborg gibi tam ya da yarı otomatikleşmiş hesap" olduğu doğrulanırken, adayların seçim kampanyalarının dışında bir gündem oluşturmaya çalışmaktadırlar. Böylece "adayların çıkarları doğrultusunda etkinlikte bulunmaktadır" hipotezi yanlışlanmaktadır. Her iki adayın takipçisi olmalarına karşın, paylaşım içeriklerinden bir çıkar grubu üyeleri gibi davranıp, kendi amaçları doğrultusunda bir AstroTurf yasama kampanyaları yürüttükleri anlaşılmaktadır. Yürüttükleri kendi gündem etkinliklerinde, paylaşımlarını diğer hesaplara ulaştırmayı başarabilmişlerdir.

Adayların hashtagler'inin diğer kullanıcılar tarafından hangi kaynaklardan dolaşıma sokulduğu Twitter API üzerinden çalışan GitHub TCAT adlı açık kaynak yazılımıyla gerçekleşmiştir. Hashtagler üzerinden yürütülen izlemede, cyborg gibi davranmaya (otomatikleşmeye) olanak veren kaynaklardan girişler her iki adayın birer hashtagler'inde bulunmaktadır. Buna karşın, İmamoğlu'nun en çok kullandığ 1 \#HerŞeyÇokGüzelOlacak hashtag'i için gerçekleşen bot girişlerine, Yıldırım'ın hiçbir hashtag'i için rastlanmamıştır. Böylece ikinci hipotezin, "adayların sosyal medya hesaplarının takipçileri içinde trollerin ve botların (dijital etki çarpanları) katkıları" kısmı doğrulanırken, katkılarının belirli düzeyde kaldığg belirlenmiştir. Tüm hesaplara bakıldığında, seçim kampanyalarında aktif normal hesapların etkilerinin azımsanmayacak kadar yüksek olduğu görülmektedir. Parti etkinliklerine angaje hareket eden ve "genç siviller", "milli görüş erleri”, “aktroller” gibi çeşitli adlarla anılan bu grupların, adayların sosyal medya hesaplarında yapay bir hareketlilik yaratabilecekleri olasıdır. Ayrıca bu grupların açtıkları etiketlerle ya da etiketlere yaptıkları yüksek miktardaki paylaşım ve yorumla Twitter gündemini manipüle etmeye dönük faaliyetler yürüttükleri bilinmektedir.

Bu araştırmada Türkiye'de Twitter trafiği içerisinde trol hesaplarının yanı sıra bot ve cyborg hesaplarının yaygın olup olmadığını belirlemeye çalışılmıştır. Amaç, adayların günlük takipçi sayılarındaki değişimi ve günlük tweet ortalamalarını, takipçilerin giriş yaptıkları kaynak platformları, oluşturulan hashtagler'in ya da sözcüklerin kullanım sıklığını, yoğun paylaşımda bulunan hesapların kime ait oldukları ve bunların kimler adına etkinliğe giriştiklerini belirlemek olmuştur. Dönemsel olarak belirli aralıklarla otomatikleşme şüphesi taşıyan farklı hesaplara rastlanmıştır. Ancak bu sınıfa girecek şüpheli hesapların her zaman takipçi listesinde ol(a)madıkları dikkat çekmektedir.

Araştırma sonucunda cyborg ve bot gibi otomatikleşmiş hesaplara rastlanmış; bu türden hesapların yalnızca siyasetçiler tarafından değil, kamu gündemi yaratmaya çalışan çıkar grupları tarafından da kullanılmaya başlandığı sonucuna ulaşılmıştır. Türkiye'de yapılan bu araştırma, otomatikleşmiş hesapları belirlemeye yönelik öncü çalışma niteliği taşımakla birlikte farklı bakış açısı sunmaktadır.

\section{Kaynaklar}

BBC, “LA Times'ta 'robot gazeteci' devri”. 18 Mart 2014. https://www.bbc.com/ turkce/haberler/2014/03/140318_robot_gazeteci.

Bradshaw, S. ve Howard, P. (2017). Troops, Trolls and Troublemakers: A Global 
Inventory of Organized Social Media Manipulation. Oxford University, Computational Propaganda Research Project, Oxford. Retrieved from http://comprop.oii.ox.ac.uk/wpcontent/uploads/sites/89/2017/07/Troops-Trolls-and-Troublemakers.pdf. Erişim Tarihi: 7 Temmuz 2018.

Buckels, E. E., Tramnell, P. D. ve Paulhus, D. (2014). "Trolls just want to have fun", Personality and Individual Differences, 67, 97-102, DOI: https://doi.org/10.1016/j. paid.2014.01.016.

Chu, Z., Gianvecchio, S., Wang, H. ve Jajodia, S. (2012). "Detecting Automation of Twitter Accounts: Are You a Human, Bot, or Cyborg?", EEE Transactions on Dependable and Secure Computing, 9 (6), 811-824. DOI: 10.1109/TDSC.2012.75.

Dominique, Jackson, (2017). “Complete Guide to Hashtag Analytics”, SproudSocial. https://sproutsocial.com/insights/hashtag-analytics/. Erişim Tarihi: 11 Mayıs 2018

Forelle, M., Howard, P., Monroy-Hernández, A. ve Savage, S. (2015, Haziran 25). "Political Bots and the Manipulation of Public Opinion in Venezuela", DOI: https:// dx.doi.org/10.2139/ssrn.2635800.

Habertürk, "Robot gazeteci dönemi başliyor". 12 Mart 2010. http://www.haberturk. com/ekonomi/teknoloji/haber/500370-robot-gazeteci-donemibasliyor.

Han, Rongbin, (2015). "Manufacturing Consent in Cyberspace: China's "FiftyCent Army", Journal of Current Chinese Affairs, 44 (2), 105-134. DOI: https://doi. org/10.1177/186810261504400205.

Harris, Ainsley, (2016). Stay Woke-With Help From A Bot, https://www. fastcompany.com/3061995/stay-woke-with-help-from-a-bot. Erişim Tarihi: 7 Temmuz 2018 .

Howard, P. N., Wooley, S. ve Calo, R. (2018). "Algorithms, bots, and political communication in the US 2016 election: The challenge of automated political communication for election law and administration", Journal of Information Technology \& Politics, 15 (2), 81-93.

Hürriyet, “AK Parti'de 'trol' s1kıntısı”. 1 Eylül 2015. http://www.hurriyet.com.tr/ gundem/ak-partide-trol-sikintisi-29959867.

Kemp, Simon, (2018, Ocak 30). "Digital Year Book in 2018: Essential Insights into Internet, Social Media, Mobile, And Ecommerce Use Around The World", Global Digital Report 2018. Hootsuit-WeareSocial. https://wearesocial.com/blog/2018/01/ global-digital-report-2018. Erişim Tarihi: 08 Temmuz 2018.

Khan, Y. ve Thakur, S. (2018). "The Presence of Twitter Bots and Cyborgs in the \#FeesMustFall Campaign". 2018 International Conference on Intelligent and Innovative Computing Applications (ICONIC) (s. 1-5). Plaine Magnien, Mauritius: IEEE. DOI:10.1109/ICONIC.2018.8601294. 
Kollanyi, B., Howard, P. N. ve Wooley, S. C. (2016). "Bots and Automation over Twitter during". Oxford University, Project on Computational Propaganda, Oxford, www. politicalbots.org.

Lanford, E. C. ve Sued, G. (2017). Hello bots! Social Media Automation Apps. Digital Methods Initiative, https://wiki.digitalmethods.net/Dmi/ SummerSchool2017MethodsMapsHelloBots. Erişim Tarihi: 15 Ağustos 2019.

Milliyet, “Japonya' da yapay zeka belediye başkanı adayı oldu”. 16 Nisan 2018. http:// www.milliyet.com.tr/japonya-da-yapay-zeka-belediye-populerbilim-haber-2649233.

Murthy, D., Powell, A. B., Tinati, R., Anstead,, N., Carr, L., Halford, S. ve Weal, M. (2016). "Automation, algorithms, and politics| bots and political influence: a sociotechnical investigation of social network capital”, International Journal of Communication, 10, 4952-4971.

Nimmo, Ben, (2016). Human, Bot or Cyborg? Three clues that can tell you if a Twitter user is fake, https://medium.com/@DFRLab/human-bot-or-cyborg-41273cdb1e17. Erişim Tarihi: 21 Ağustos 2018.

Posta, “Japonya'da yapay zeka robotu belediye başkanlığına aday oldu!”. 17 Nisan 2018. http://www.posta.com.tr/japonya-da-yapay-zeka-robotubelediyebelediyebaskanligina.

Saka, Erkan, (2016). “Siyasi Trollük Örneği Olarak Aktroller”, Birikim, (322), 1721.

Saka, Erkan, (2018). "Social Media in Turkey as a Space for Political Battles: AK Trolls and other Politically motivated trolling", Middle East Critique, 27 (2), 161-177. DOI: $10.1080 / 19436149.2018 .1439271$.

Sanovich,, S., Stukal, D. ve Tucker, J. A. (2018). "Turning the Virtual Tables: Government Strategies for Addressing Online Opposition with an Application to Russia", ComparativePolitics,50(3),435-482.DOI:https://doi.org/10.5129/001041518822704890.

Sözcü, "Robot gazeteci ayda 30 bin haber üretecek". 31 Temmuz 2017. https:// www.sozcu.com.tr/2017/ekonomi/robot-gazeteci-ayda-30-bin-haber-uretecek.

Symantec Corporotion. (2018, Temmuz 3). Uk.Norton. https://uk.norton.com/tools/ bots/index.html\#izmir. Erişim Tarihi: 03 Temmuz 2018.

Ülkcü Medya, "Mahkum Yakınları 23 Haziran İstanbul Seçiminde Kimi Destekleyeceğini Açıkladı", 26 Nisan 2019. https://www.ulkucumedya.com/mahkumyakinlari-23-haziran-istanbul-seciminde-kimi-destekliyecegini-acikladi-123690h.htm.

Wooley, S. C. ve Howard, P. N. (2016). "Political Communication, Computational Propaganda, and Autonomous Agents", International Journal of Communication, 10 (9), 4882-4890. 


\section{EKLER}

\section{Ek-1}

\section{Yılına Ait Twitter Bot ve Otomasyon Hizmet Örnek Fiyatlandırmaları}

\begin{tabular}{lcc}
\hline Facebook & $\begin{array}{c}\text { Türk } \\
\text { Takipçi }\end{array}$ & $\begin{array}{c}\text { Türk Sayfa } \\
\text { Beğeni }\end{array}$ \\
Kişi & TL & TL \\
1.000 & 60,00 & 40,00 \\
2.500 & 125,00 & 200,00 \\
5.000 & 250,00 & 400,00 \\
50.000 & $2.500,00$ & 800,00 \\
10.000 & - & $7.000,00$ \\
\hline
\end{tabular}

Trend Topic 1 hashtag 400 TL

1 saat

(takipcisatinal.org)

\begin{tabular}{lc}
\hline \multicolumn{1}{c}{ Twitter } & Trend Topic \\
Saat & TL \\
$\mathbf{1}$ & 650 \\
$\mathbf{2}$ & 1.150 \\
$\mathbf{3}$ & 1.650 \\
$\mathbf{4}$ & 2.300 \\
\hline \multicolumn{3}{c}{ (takipcisatinal.com) }
\end{tabular}

\begin{tabular}{lccc}
\hline Twitter & $\begin{array}{c}\text { Türk } \\
\text { Gerçek } \\
\text { Takipçi }\end{array}$ & $\begin{array}{c}\text { Türk Bot } \\
\text { Takipçi }\end{array}$ & $\begin{array}{c}\text { Türk Bot } \\
\text { (K/E) Takipçi }\end{array}$ \\
Kişi & TL & TL & TL \\
250 & 9,25 & 12,00 & 18,00 \\
500 & 17,00 & 22,00 & 33,00 \\
1.000 & 24,00 & 40,00 & 60,00 \\
2.500 & 72,50 & 97,50 & 147,50 \\
5.000 & 140,00 & 190,00 & 290,00 \\
10.000 & - & 360,00 & 570,00 \\
100.000 & - & $3.500,00$ & - \\
\hline
\end{tabular}

Otomatik Retweet ve Beğeni Adet TL Adet TL

$\begin{array}{llll}\mathbf{5 0} & 150 & 100 & 10,00\end{array}$

$100 \quad 235 \quad 250 \quad 20,00$

$350 \quad 500 \quad 500 \quad 30,00$

$500 \quad 1.000 \quad 5.000 \quad 250,00$

$\mathbf{1 0 . 0 0 0} \quad-\quad 10.000 \quad 450,00$

$\mathbf{2 0 . 0 0 0} \quad-\quad 20.000 \quad 900,00$

\begin{tabular}{lcc}
\hline & & \\
\hline Twitter & Türk & Türk Bot Takipçi \\
& Takipçi & TL \\
Adet & TL & 25,00 \\
$\mathbf{5 0 0}$ & 25,00 & \\
$\mathbf{1 . 0 0 0}$ & 250,00 & 250,00 \\
$\mathbf{1 0 . 0 0}$ & 620,00 & 620,00 \\
$\mathbf{2 5 . 0 0 0}$ & $1.200,00$ & $1.200,00$ \\
$\mathbf{5 0 . 0 0 0}$ & $2.300,00$ & $2.300,00$ \\
$\mathbf{1 0 0 . 0 0 0}$ & $3.500,00$ & $3.500,00$ \\
$\mathbf{1 5 0 . 0 0 0}$ & - & \\
\hline
\end{tabular}

(takipcisatinal.com) 


\begin{tabular}{lcccc}
\hline Twitter & $\begin{array}{c}\text { Türk } \\
\text { Gerçek } \\
\text { Beğeni }\end{array}$ & $\begin{array}{c}\text { Türk Gerçek } \\
\text { Yavaş Beğeni }\end{array}$ & $\begin{array}{c}\text { Türk Bot } \\
\text { Beğeni }\end{array}$ & $\begin{array}{c}\text { Türk Bot } \\
\text { Yavaş Beğeni }\end{array}$ \\
Adet & TL & TL & TL & TL \\
250 & 7,25 & 8,00 & 6,75 & 7,00 \\
1.000 & 25,00 & 28,00 & 24,00 & 25,00 \\
5.000 & 115,00 & 130,00 & 110,00 & 115,00 \\
10.000 & 210,00 & - & 200,00 & - \\
\hline
\end{tabular}

(takipcisatinal.org) 
Ek-2

23 Haziran 2019 seçimlerine katılan Cumhur İttifakı ve Millet İttifakı adaylarının ve kendi partilerinin hashtagler'i

\begin{tabular}{|c|c|c|}
\hline \multirow{2}{*}{$\begin{array}{l}\text { Aday Olunan Şehir } \\
\text { Aday }\end{array}$} & \multicolumn{2}{|c|}{ İstanbul } \\
\hline & Binali Yıldırım@BA_Yildirim & Ekrem İmamoğlu@ekrem_imamoglu \\
\hline Adaylık Tarihi & 29.12 .2018 & 18.12.2018 \\
\hline $\begin{array}{l}\text { Kendi Kampanya } \\
\text { slogani/hashtagi }\end{array}$ & $\begin{array}{c}\text { \#yaparsaakpartiyapar } \\
\text { \#kolayİstanbul } \\
\text { \#gönülbelediyeciliği } \\
\text { \#DahaGüzelOlacak } \\
\text { \#BinaliYıldırımDemek } \\
\text { \#HaydiTürkiye }\end{array}$ & $\begin{array}{l}\text { \#İmamoğluvarsaÇözümvar } \\
\text { \#herŞeyÇokgüzelolacak } \\
\text { \#İstanbulunUmuduİmamoğlu }\end{array}$ \\
\hline $\begin{array}{l}\text { Parti kampanya } \\
\text { slogani/hashtagi }\end{array}$ & $\begin{array}{c}\text { \#memleketİşigönülİşi } \\
\text { \#belediyeİşigönülİşi } \\
\text { \#gönülbelediyeciliğikampı } \\
\text { \#YineBizYaparız }\end{array}$ & \#MartınSonuBahar \\
\hline $\begin{array}{l}\text { Parti Başkanı } \\
\text { Hashtag }\end{array}$ & \#ÖncemilletÖncememleket & \#milletİçingeliyoruz \\
\hline İttifak Hashtag & \#cumhurittifakı & \#milletittifak1 \\
\hline
\end{tabular}

